\title{
Romanian letter-writing: a cultural-rhetorical perspective (II)
}

\author{
Gabriela-Iuliana $\operatorname{Morcov}^{1}$, Ioan Milică ${ }^{2 *}$ \\ ${ }^{1}$ Doctoral School of Philological Studies, "Alexandru Ioan Cuza” University, Bd. Carol I 11, 700506 Iaşi, Romania \\ ${ }^{2}$ Faculty of Letters, "Alexandru Ioan Cuza" University, Bd. Carol I 11, 700506 Iassi, Romania
}

\section{Article info}

History:

Received March 23, 2016

Accepted April 12, 2016

Published August 1, 2016

Key words:

letter

rhetoric

functionalism

Romanian epistolary style

\begin{abstract}
The article aims at revealing the features of Romanian letter-writing during its stages of formation and consolidation. The structural and the stylistic analysis of letters is carried out with regard to the composition of the documents written in Old Romanian according to the requirements imposed by the Slavonic template and with regard to the rhetorical division of the three styles: the simple style, the middle style and the grand style. The description of the Old Romanian epistolary style is based on a taxonomy inspired by Roman Jakobson's functional communicative model (1964). Following the six factors identified by Jakobson, letters are classified according to the socio-cultural status and the communicative competence of the addresser and of the addressee and in line with the context, the channel and the linguistic code used to write them.
\end{abstract}

"How should the conversation be? It should be clear and simple. These are also the two features of letter-writing." C. Donescu, Epistolariu culesu shi întocmitu asfelu..., 1840

\section{The Romanian epistolary style: a rhetorical analysis}

\subsection{The structure and the stylistic features of the epistolary text}

The fact that letters had been written in Slavonic or in other languages of diplomacy narrowed the range of epistolary exchanges inasmuch as letter-writing was confined to certain privileged social categories: rulers, high clergy, high officials or boyars. Even in the subsequent period of time, when a growing tendency of writing in the vernacular language was witnessed, letters would continue to be employed mainly by the learned people. However, as one can find in the surviving documents, the addressers of the epistles dating from around the $17^{\text {th }}$ century came also from the middle of simple, uneducated people, and most of the time the success of their written interaction was dependent on the intervention of the scribe. In addition to the practical function of their activity, which was that of enabling the written conveyance of messages, we ought to mention the contribution that the professional writers of that time (chancellors, priests, learned boyars etc.) made to the establishment and diffusion of a general form over the age.

Throughout the $16^{\text {th }}$ and the $17^{\text {th }}$ centuries the conventions of writing are set by the royal chanceries and this is the main reason why the epistolary formulary crafted after the Slavonic template is relatively uniform and not fundamentally different from the pattern of other legal and administrative acts. Most documents of the time rigorously include three main divisions-the initial protocol, the context, and the final protocol—with their corresponding divisions (see Table 1) that Alexandru Mareş outlines in his introduction to Documente și insemnări românești din secolul al XVI-lea [16 ${ }^{\text {th }}$ Century Romanian Documents and Memoranda]. Letters preserve just in part the structural elements of the general template, and, in different interactions, varying according to their purposes as well as the strategies they rely on, some compositional elements may be omitted, may be conventionally formulated, or, on the contrary, may be devised in a solemn, reverential or familiar tone.

\footnotetext{
*Email address: ioanister@gmail.com.
} 
The initial protocol is primarily composed by the address / inscription, including the name, the title and the quality of the addressee, and the salutation. The context of letters displays only certain constitutive elements that generally structure the official documents. The notification is usually expressed by such linguistic formula as dau (dăm) in știre [I/we let you know] and precede the exposition, which consists of a report on the events and the circumstances that lead to the writing of the letter. Even if disposition, proviso, sanction, and corroboration are not typical divisions in letter-writing, some of them may exceptionally occur to signal the authority of the addresser or to act as persuasive intensifiers intended for certain categories of addressees or audiences. The final protocol gains a great significance in the eyes of letter-writers. One of its defining components is the valediction, usually inserted after the exposition, and, depending on the circumstances of the epistolary exchange, it may be omitted or it may be used as a marker of genuine reverence and solemnity. The date indicates the place and the time of writing and, when it occurs, it is stated after the valediction. Some of the surviving document from the $16^{\text {th }}$ and the $17^{\text {th }}$ centuries close through one or more attestations, and the seal is most frequently used in letter-writing.

\begin{tabular}{l|c} 
Initial protocol & $\begin{array}{c}\text { symbolic (verbal) invocation } \\
\text { superscription } \\
\text { address } \\
\text { salutation }\end{array}$ \\
\hline Context & $\begin{array}{c}\text { notification } \\
\text { exposition }\end{array}$ \\
disposition / the injunction \\
$*$ proviso / the prohibitive clause \\
sanction \\
corroboration \\
valediction
\end{tabular}

Table 1: The formulary of the Old Romanian documents (Chivu et al., 1979, p. 35-47)

It is St. Augustine who deserves the credit for having adapted the threefold division of style-the simple style, the middle style and the grand style - to the stylistic needs of Christian oratory (see, for instance, Milică, 2015) and, implicitly, to the art of letter writing, by means of the rhetorical analysis of the Pauline epistles in the light of the classical precepts of elocution. A millennium later, the $15^{\text {th }}$ century Renaissance scholars would reframe the threefold division of style ${ }^{1}$ to suit the compositional requirements of secular epistolary theory (Mack, 2011, p. 236). The refinement could have fallen into place as the austere simple style had been recognized, since the classical age, as the basic means of composition in letter-writing. It is probably by the virtue of tradition that the contemporary studies of rhetoric and stylistics implicitly value the legacy of clarity and correctness in handbooks that describe various strategies of compositional adequacy, concordant with the expressive necessities of any given type of correspondence (Bly, 2004) as well as in theoretical works that advocate the existence of three epistolographical genres (varieties): familiar, formal and solemn (Irimia, 1999, p. 159; Dumistrăcel, 2007, p. 74-77).

In the writings of Cicero, the ancient rhetorician mostly revered, read and imitated by the Medieval and the Renaissance authors of letter-writing manuals and treatises, the threefold division of style is correlated with the orator's persuasive ends (Cicero, 1939, p. 357f). Moreover, in Retorica ad Herennium (1964, p. 253), a classical book of rhetoric of assiduous use in the Renaissance, the threefold division of style is briefly exposed ${ }^{2}$ as if such a doctrine were well and widely known.

\footnotetext{
${ }^{1}$ Some of the exegetes credit Teophrastus, Aristotle's disciple, with the authorship of the ternary canon of style: the simple style (humble), the middle style (common, moderate, temperate), and the grand style (sublime, solemn, serious).

2"There are, then, three kinds of style, called types, to which discourse, if faultless, confines itself: the first we call the Grand;
} 
Cicero meticulously records the features of each style. The orator who delivers a speech composed in simple style speaks with clarity and modesty, so that the discourse should not stand in contrast with that of those who are not versed in the art of elocution. The simple style aims at informing and instructing the audience. Therefore, the rhetorical prowess should not be shown by dashing words, but by accurate ideas, so that "the audience, even if they are no speakers themselves, are sure they can speak in that fashion" (Cicero, 1939, p. 263). The construction of discourse and its delivery should reflect the virtues of plainness. The speech should be free of any striking or artificial stylistic adornment, the language, though plain, should be correctly used, the utterances should be clear and precise, and the concern for accuracy should unmistakeably underline the discourse. The essence of simple style lies in expressing insightful, genuine and profound ideas conveyed in a precise, clear and austere language.

In line with such precepts, various authors of letter-writing treatises regard the simple style as the most appropriate type of elocution to be used in familiar letters. Romanian epistolary practices ${ }^{3}$ reveal that this type of composition is most frequently met in the exchange of letters among family members (Tabela 2):

Table 2: Examples of simple style letters

\begin{tabular}{|c|c|c|c|c|}
\hline & & Mărica Mătiiasa & Cocrișel & Ștefan Brîncoveanu \\
\hline \multirow[t]{4}{*}{$\begin{array}{l}\text { Initial } \\
\text { protocol }\end{array}$} & $\begin{array}{l}\text { symbolic } \\
\text { invocation }\end{array}$ & & $t$ & \\
\hline & $\begin{array}{l}\text { super- } \\
\text { scription }\end{array}$ & $\begin{array}{l}\text { Eu, Mărica Mătiiasa din } \\
\text { țara Moldovei, din satul } \\
\text { din Stăjăreni [I, Mărica } \\
\text { Mătiasa, in the land of } \\
\text { Moldavia, from the } \\
\text { village of Stăjăreni] }\end{array}$ & & \\
\hline & address & $\begin{array}{l}\text { (scriu) la tine, bărbate } \\
\text { Mătei, carele sezi în Țara } \\
\text { Ungurească [(I write) to } \\
\text { you, my husband Matei, } \\
\text { who lives in Hungary] }\end{array}$ & $\begin{array}{l}\text { părinteloi meu }<\text { Spi>ridon și } \\
\text { maiciei méle Costandeei [to } \\
\text { my father Spiridon and my } \\
\text { mother Costandeea] }\end{array}$ & $\begin{array}{l}\text { Cinstită dumneata mamă } \\
\text { [My honoured mother] }\end{array}$ \\
\hline & salutation & & $\begin{array}{l}\text { Scriu închinăciune şi moltă } \\
\text { sănătate [I am devotedly } \\
\text { yours and I wish you good } \\
\text { health] }\end{array}$ & $\begin{array}{l}\text { cu plecăčune sărut cinstită } \\
\text { măna dumitale și rog pre } \\
\text { puternicul Dumnezeu să } \\
\text { dăruiască dumitale fericită } \\
\text { sănătate inpreună cu tot binele } \\
\text { [I most respectfully kiss your } \\
\text { hand and pray to the } \\
\text { Almighty God to bless you } \\
\text { with good health and } \\
\text { all the best] }\end{array}$ \\
\hline Context & notification & $\begin{array}{l}\text { dau-țiștire [I let you } \\
\text { know] }\end{array}$ & $\begin{array}{l}\text { Si dup-acéia vă dau știre [And } \\
\text { then I let you know] }\end{array}$ & $\begin{array}{l}\text { Pricina scrisorii mele către } \\
\text { dumneata de astă dată de alt } \\
\text { nu ieste făr numai, întăi, să } \\
\text { aflu de buna și mie mult } \\
\text { veselitoare sănătate } \\
\text { dumneavostră; a doao ca să } \\
\text { aduc dumitale bună vestire }\end{array}$ \\
\hline
\end{tabular}

the second, the Middle; the third, the Simple. The Grand type consists of a smooth and ornate arrangement of impressive words. The Middle type consists of words of a lower, yet not of the lowest and most colloquial, class of words. The simple type is brought down even to the most current idiom of standard speech." (Retorica ad Herennium, 1964, p. 253).

${ }^{3}$ The epistolary fragments quoted in this study are mainly excerpted from the collection Documenta Romanize Historica (DRH): Documenta Romanic Historica. A. Moldova, Editura Academiei Române, București, 1969-2006 (DRH A), and Documenta Romanie Historica. B. Țara Românească, Editura Academiei Române, București, 1965-2006 (DRH B). 


\begin{tabular}{|c|c|c|c|c|}
\hline & & & & $\begin{array}{l}\text { [The reason why I write to } \\
\text { you is none other than first to } \\
\text { hear of your good health and } \\
\text { second to give you the good } \\
\text { news] }\end{array}$ \\
\hline & exposition & $\begin{array}{l}\text { cum eu-s beteagă și, de } \\
\text { casă, nu-s de a ținè; [ [that I } \\
\text { am in poor health and I } \\
\text { can no longer keep the } \\
\text { house;] că eu am } \\
\text { bolnăvit; [I fell sick;] Iar } \\
\text { eu mă voiu ține aicea, in } \\
\text { Moldova, lîngă oamenii } \\
\text { miei, pînă cînd voi custa; } \\
\text { [and I will stay here, in } \\
\text { Moldavia, with my } \\
\text { people for the rest of my } \\
\text { life;] }\end{array}$ & $\begin{array}{l}\text { Deci mă rog domnilor vostre } \\
\text { ca lui Domnedză<u> den } \\
\text { ceriu să nefoiți <să > mă scoteți } \\
\text { lîngă voi în țară creștină (...) } \\
\text { că eu dzacu în timniță de mă } \\
\text { mănî<n>că liutul și } \\
\text { pă<du>chie; [So I am } \\
\text { begging you as I would pray } \\
\text { to God from Heaven to strive } \\
\text { to gain my release to the } \\
\text { Christian land (...) from the } \\
\text { prison where my body itches } \\
\text { with lice and dirt; } \\
\text { Deci iară mă rog domnilor } \\
\text { vostre să no mă zăbăviț aici } \\
\text { (...) că iu mor de dorol vostru. } \\
\text { Si înbătrănesco, și am făcoto } \\
\text { barbă pînă in brîu. [So I beg } \\
\text { you once more not to leave } \\
\text { me here (...) because I miss } \\
\text { you dearly and I am getting } \\
\text { old and have grown a } \\
\text { waist-long beard.] }\end{array}$ & 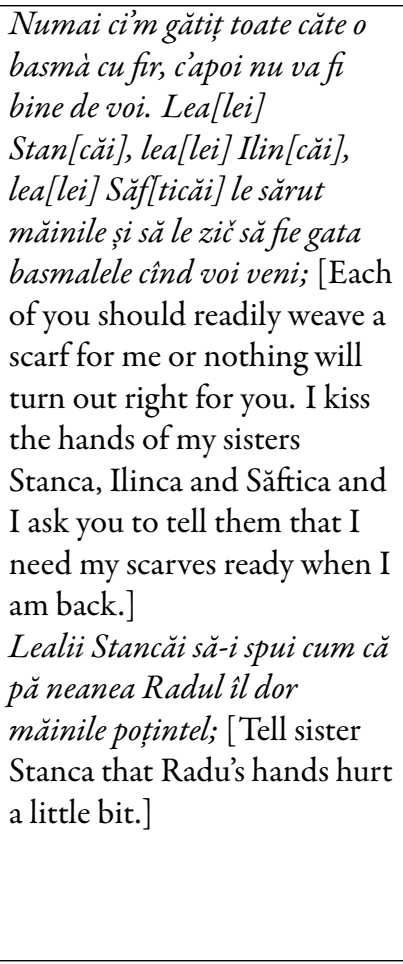 \\
\hline & disposition & & & \\
\hline & $\begin{array}{l}\text { prohibitory } \\
\text { clause }\end{array}$ & & & \\
\hline & sanction & & & \\
\hline & corroboration & & & \\
\hline $\begin{array}{l}\text { Final } \\
\text { protocol }\end{array}$ & valediction & $\begin{array}{l}\text { Şi să fii sănătos, amin. } \\
\text { [May you be in good } \\
\text { health, amen.] }\end{array}$ & $\begin{array}{l}\text { Si }<s>a ̆ \text { afle aiasta scrisore a } \\
\text { mea sănătos pre domeavostră, } \\
o \text { G<ospod }>i \text {, amin. [May } \\
\text { this letter find you both in } \\
\text { good health, amen.] }\end{array}$ & $\begin{array}{l}\text { Mila lui Dumnezău să } \\
\text { păzească pre dum. [May the } \\
\text { grace of God protect you!] }\end{array}$ \\
\hline & date & $\begin{array}{l}\text { Şi am scris în sat } \\
\text { Stăjăreni, Iunie } 13 \text { zile }\end{array}$ & & Mai 27 dn., lt. 7211 \\
\hline & $\begin{array}{l}\text { attestation } \\
\text { (subscrip- } \\
\text { tions, seals } \\
\text { etc.) }\end{array}$ & & $\begin{array}{l}+F<e>\text { ciorol vostru Cocrișel; } \\
\text { și simtu nomai co că }<m e s ̦ a>\text {. } \\
\text { [Your son, Cocrişel; with } \\
\text { only a shirt a wear.] }\end{array}$ & $\begin{array}{l}\text { Aldum. de fii cei mici şi } \\
\text { plecat. Şt. B." [Your youngest } \\
\text { and obedient son, Şt. B.] }\end{array}$ \\
\hline
\end{tabular}

According to Cicero, the middle style is supposed to be elegant and pleasing. The rhetorician states that this elocutional type allows for simple and dignified ornaments because "as a matter of fact, a brilliant and florid, highly coloured and polished style in which all the charms of language and thought are intertwined" (Cicero, 1939, p. 375). In Old Romanian letter-writing practices, the middle style was used in the official correspondence of the high nobility and the high clergy, or in letters sent from the royal chancery to the members of the aristocracy and of the church (Table 3): 
Table 3: Examples of middle style letters

\begin{tabular}{|c|c|c|c|c|}
\hline & & Alexandru Coconul voievod & Mihai Viteazul & $\begin{array}{l}\text { Episcopul Serafim al } \\
\text { Buzăului }\end{array}$ \\
\hline \multirow{4}{*}{$\begin{array}{l}\text { Initial } \\
\text { protocol }\end{array}$} & $\begin{array}{l}\text { symbolic } \\
\text { invocation }\end{array}$ & & $t$ & $t$ \\
\hline & $\begin{array}{c}\text { super- } \\
\text { scription }\end{array}$ & $\begin{array}{l}\text { Cu mila lui Dumnezeu, Io } \\
\text { Alexandru voevod și domn, } \\
\text { feciorul răposatului Io Radu } \\
\text { voevod. [By the grace of } \\
\text { God, I Alexander Voivode } \\
\text { and Lord, son of the Late } \\
\text { Radu Voivode.] }\end{array}$ & & \\
\hline & address & $\begin{array}{l}\text { Scris-am domniia mea voăo } \\
\text { satul Marotinul [I am } \\
\text { writing to you, the people of } \\
\text { Marotin village] }\end{array}$ & $\begin{array}{l}\text { Bane Mihalcio și tu, vistiiar } \\
\text { Stoico [To you, Ban Mihalcea } \\
\text { and to you, treasurer Stoico] }\end{array}$ & $\begin{array}{l}\text { Prea milostive și prea } \\
\text { luminate doamne [Most } \\
\text { graceful and blessed Lord] }\end{array}$ \\
\hline & salutation & & & $\begin{array}{l}\text { să fii măriia ta sănătos. } \\
\text { Milostivul Dumnezeu să-ți } \\
\text { dăruiască tot binele măriii } \\
\text { tale. [May Your Highness be } \\
\text { in good health. May the } \\
\text { Merciful God bestow His } \\
\text { blessings upon Your } \\
\text { Highness.] }\end{array}$ \\
\hline \multirow[t]{2}{*}{ Context } & notification & $\begin{array}{l}\text { După aceia, vă dau în ştire } \\
\text { domniia mea [And I let you } \\
\text { know] }\end{array}$ & $\begin{array}{l}\text { dau-vă in știre [I let you } \\
\text { know] }\end{array}$ & $\begin{array}{l}\text { Alta fac în știre măriii tale } \\
\text { [And I also let Your } \\
\text { Highness know] }\end{array}$ \\
\hline & exposition & $\begin{array}{l}\text { Adevăr domniia mea văz și } \\
\text { crez că ați avut păs și greu nu } \\
\text { numai voi, ci și toată țara. Şi } \\
\text { domniia mea încă am avut } \\
\text { destule grele (...) [I truly see } \\
\text { and believe that there have } \\
\text { been sorrows and burdens } \\
\text { for you and for the whole } \\
\text { country and I have been } \\
\text { through many hardships } \\
\text { myself }(. . .) \text { ] }\end{array}$ & $\begin{array}{l}\text { pentru omul cistitului } \\
\text { impărat, ce-au trimes la noi; } \\
\text { [about the messenger of his } \\
\text { imperial grace, whom they } \\
\text { sent to us; ] } \\
\text { ce noi, cum au fost porunca } \\
\text { impăratului și cum au fost } \\
\text { scris în cărțile măriii lui la } \\
\text { noi, ce ne va fi pohta noi să } \\
\text { dăm în știre impărățiii lui de } \\
\text { toate; ce, într-aceaea noi, de } \\
\text { ce ne-au fost pohta am scris tot } \\
\text { intr-această carte ce am } \\
\text { trimes la domneavoastră.; } \\
\text { [and we, according to the } \\
\text { emperor's will written in His } \\
\text { Highness' letters to us that } \\
\text { we should let His Highness } \\
\text { know about all our requests, } \\
\text { wherefore have written all } \\
\text { our requests in this letter to } \\
\text { you;] } \\
\text { iar voi să căutațpre această } \\
\text { pobtă ce-am pohtit noi.; [and } \\
\text { you shall meet our requests; } \\
\text { și, in vreamea ce veți tocmi } \\
\text { pre această tocmeală, voi cum } \\
\text { mai curind, de olac, să-m } \\
\text { trimeateți om cu carte de olac, } \\
\text { să-m dat în știre domniii } \\
\text { meale. Şi am dat învățătură }\end{array}$ & $\begin{array}{l}\text { că aici înaintea smereniei } \\
\text { noastre venit-au Radul } \\
\text { portarul cu răvașele măriii } \\
\text { tale; [that boyar Radu came } \\
\text { to our humble door with } \\
\text { Your Highness' letters; ] } \\
\text { Dereptu aceea, cum au jurat } \\
\text { ei și cum au mărturisit ei cu } \\
\text { sufletele lor innaintea smerenii } \\
\text { noastre și au luat și blästem } \\
\text { cu ofurisanie după jurămîntul } \\
\text { lor, smereniia noastră incă fac } \\
\text { in știre măriii tale. Măriia ta } \\
\text { ești bun şi milostiv, ci vei face } \\
\text { cum te va năstăvi milostivul } \\
\text { Dumnezeu. [That is why I } \\
\text { let Your Highness know that } \\
\text { they have sworn on their } \\
\text { souls and have taken an oath } \\
\text { in front of us and that I } \\
\text { placed a curse on them } \\
\text { should they break the oath. } \\
\text { Your Highness is kind and } \\
\text { merciful and you will act } \\
\text { according to God's will.] }\end{array}$ \\
\hline
\end{tabular}




\begin{tabular}{|c|c|c|c|c|}
\hline & disposition & $\begin{array}{l}\text { Deci, de vreme ce veți vedea } \\
\text { această carte a domnii mele, } \\
\text { iar voi să căutați să vă } \\
\text { inturnați pre la casele voastre, } \\
\text { să vă apucați de plug și de } \\
\text { brană, iar de către domniia } \\
\text { mea veți avea pace și răpaos } \\
\text { (...) Iar alt val sau bîntuială } \\
\text { de către domniia mea nimica } \\
\text { nu veți mai avea de acuma } \\
\text { innainte. [Therefore, as soon } \\
\text { as you receive my Lordship’s } \\
\text { letter, go back to your } \\
\text { households, and start } \\
\text { ploughing the fields, and I } \\
\text { will let you live in peace (...). } \\
\text { Henceforth, you shall no } \\
\text { longer suffer any sorrow or } \\
\text { attack for my part.] }\end{array}$ & $\begin{array}{l}\text { și lui Pandazi logofăt ce vă va } \\
\text { spune și den gură, aceaea vă } \\
\text { dau in știre [and, as soon as } \\
\text { you reach an agreement, you } \\
\text { shall send me a messenger. I } \\
\text { have also instructed } \\
\text { chancellor Pandazi to tell } \\
\text { you my will] }\end{array}$ & \\
\hline & proviso & $\begin{array}{l}\text { Intr-alt chip să nu fie, după } \\
\text { zisa domnizai mele. Şi însumi } \\
\text { am zis domniia mea. [This is } \\
\text { my will and you shall not do } \\
\text { any different.] }\end{array}$ & & \\
\hline & sanction & & & \\
\hline & corroboration & & & \\
\hline $\begin{array}{l}\text { Final } \\
\text { protocol }\end{array}$ & valediction & & $\begin{array}{l}\text { I } \tilde{B} \tilde{u} \text { vi ve(s)li(t), ami }(n) \text {. } \\
\text { [May God bless you with } \\
\text { happiness.] }\end{array}$ & $\begin{array}{l}\text { Мипость Бөжї̈ стово и } \\
\text { господства та [May the } \\
\text { grace of God be upon Your } \\
\text { Highness] }\end{array}$ \\
\hline & date & $\begin{array}{l}\text { Scris maiu } 5 \text { zile, vă leat } \\
7135<1627>\text { [Written on } \\
\text { the } 5 \text { th of May, } 7135 \\
<1627>\text { ] }\end{array}$ & $\begin{array}{l}P i(s) g e(n) 26 d(n), 1600 \\
\text { [Written on the } 26^{\text {th }} \text { of } \\
\text { January, 1600] }\end{array}$ & \\
\hline & attestation & & $\begin{array}{l}\text { Io Mihail vodă (autografă) } \\
\text { [I, Michael Voivode } \\
\text { (autograph subscription) - } \\
\text { red wax annular seal, } \\
\text { timeworn, belonging to } \\
\text { Michael the Brave] }\end{array}$ & $\begin{array}{l}\text { Gмћремны епискшп } \\
\text { Gерафим Б8ззевскїи [The } \\
\text { humble bishop Serafim of } \\
\text { Buzău] }\end{array}$ \\
\hline
\end{tabular}

The grand style is the eloquence that sways "men's minds and move them in every possible way" (Cicero, 1939, p. 377). In oratory, this type of elocution is the amplest, the richest and the brightest. The orator that masters the simple style is skilful and ingenious, a master of the temperate style is confident and balanced, but the refinement presumed of the grand style requires vigour, sagacity and ardour. The grand style captures the audience, penetrates the souls, "implants new ideas and uproots the old" (Cicero, 1939, p. 377). The grand epistolary style is used in the solemn correspondence between kings or between erudites and it is rarely used in old Romanian letter-writing (Table 4): 
Table 4: Examples of grand style letters

\begin{tabular}{|c|c|c|c|}
\hline & & King Ludovic I of Hungary & Voivode Constantin Brîncoveanu \\
\hline \multirow{4}{*}{$\begin{array}{l}\text { Initial } \\
\text { protocol }\end{array}$} & $\begin{array}{l}\text { symbolic } \\
\text { invocation }\end{array}$ & & $t$ \\
\hline & $\begin{array}{c}\text { super- } \\
\text { scription }\end{array}$ & $\begin{array}{l}\text { Ludovicus, dei gratia, Hungarie, Dalmatie, } \\
\text { Croatie, Rame, Servie, Gallicie, Lodomerie, } \\
\text { Cumanie, Bulagarieque rex, princeps } \\
\text { Salernitanus, et honoris Montis sancti Angeli } \\
\text { dominus [Ludovic, by the grace of God, } \\
\text { king of Hungary, Dalmatia, Croatia, Rama, } \\
\text { Serbia, Cumania, and Bulgaria, prince of } \\
\text { Salerno, and ruler of Mount Sant'Angelo] }\end{array}$ & $\begin{array}{l}\text { Io Constantin Voevod, cu mila lui } \\
\text { Dumnezeu Domn al Țerii-Românești [I } \\
\text { Constantin Voivode, by the grace of God, } \\
\text { ruler of Wallachia] }\end{array}$ \\
\hline & adresa & $\begin{array}{l}\text { omnibus Christi fidelibus, tam presentibus, } \\
\text { quam futuris, presentem paginam inspecturis } \\
\text { [to all the devoted followers of Christ, } \\
\text { present or future, who will see this letter] }\end{array}$ & $\begin{array}{l}\text { T Cinstititilor și ai noștri buni prieteni și } \\
\text { vecini de aproape, in toată vremea de bine } \\
\text { voitori, dumnealor tot cinstitul Sfat al } \\
\text { cinstitei cetăți Braşovul [To our } \\
\text { honourable, always benevolent, good } \\
\text { friends and close neighbours, the council of } \\
\text { the esteemed city of Brasov] }\end{array}$ \\
\hline & salutation & $\begin{array}{l}\text { salutem in omnium salvatore [may you find } \\
\text { salvation in the Saviour of all mankind] }\end{array}$ & $\begin{array}{l}\text { sănătate și tot binele poftim d-voastră de la } \\
\text { Dumnezeu. [We wish you good health and } \\
\text { God's blessings.] }\end{array}$ \\
\hline \multirow{6}{*}{ Context } & notification & & \\
\hline & exposition & $\begin{array}{l}\text { Regie sublimitatis honore primarumque } \\
\text { executione decoratur, ut attentionis sue } \\
\text { gratitudinis studio illic omnem reprimat, } \\
\text { aciem sue mentis, unde noverit celsitudinis } \\
\text { munus recepisse, tantoque in sua gloria } \\
\text { clarior permanet, quanto in divinis cultibus } \\
\text { et religiosorum considerationibus solertior } \\
\text { invenitur; [The greatness of royalty and of } \\
\text { God's unbounded realm grows whenever } \\
\text { the king looks fervently and sharply } \\
\text { towards the source of his highness and it } \\
\text { will last the more in the light of its glory } \\
\text { the more it is devoted onto praising God } \\
\text { and carrying for the devout.] } \\
\text { Nos itaque, instantissimis supplicationibus } \\
\text { eorundem fratrum cruciferorum nobis } \\
\text { porrectis inclinati advertentes, quodper tales } \\
\text { versutias hominum perversorum possessiones } \\
\text { dicti ordinis alienarentur ab eodem, } \\
\text { cupientes igitur eisdem fratribus per } \\
\text { oportun a subsidia succurrere in premissis etc. } \\
\text { [We are, therefore, moved by the relentless } \\
\text { plea of these cross-bearing brothers in } \\
\text { Christ, and, noting that the land of the } \\
\text { order was taken by such vile conspiracies of } \\
\text { evil men, it is our will to help these } \\
\text { brothers by taking appropriate measures.] }\end{array}$ & 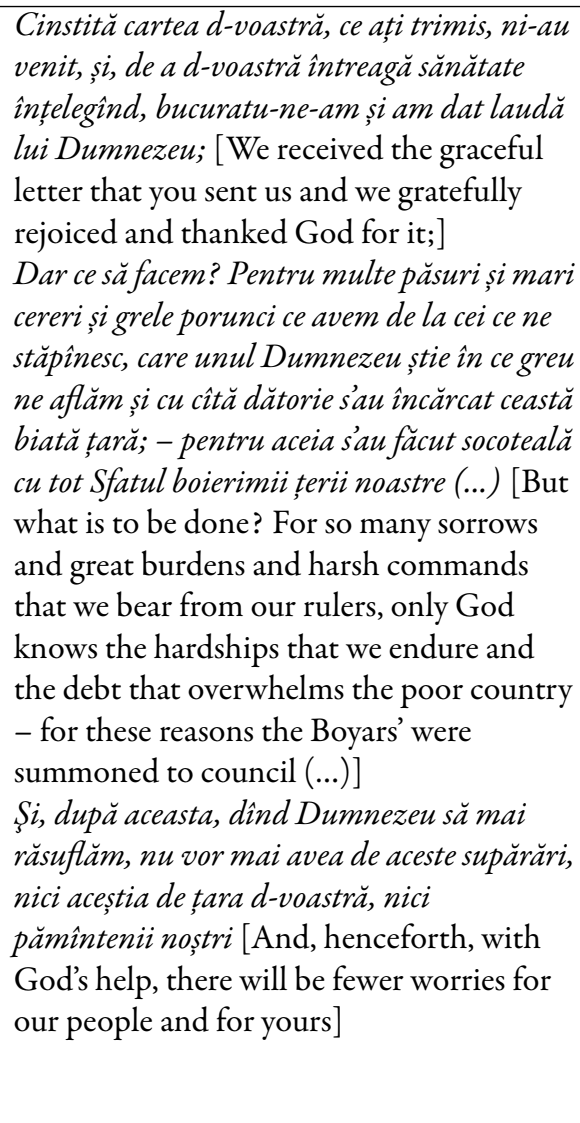 \\
\hline & disposition & & \\
\hline & $\begin{array}{l}\text { prohibitive } \\
\text { clause }\end{array}$ & & \\
\hline & sanction & & \\
\hline & corroboration & $\begin{array}{l}\text { In cuius rei memoriam perpetuamque } \\
\text { firmitatem presentes concessimus nostras } \\
\text { literas privilegiales, pendentis et authentici } \\
\text { sigilli nostri dupplicis munimine roboratas. }\end{array}$ & \\
\hline
\end{tabular}




\begin{tabular}{|c|c|c|c|}
\hline & & $\begin{array}{l}\text { [To the everlasting and enduring memory } \\
\text { of our will, we hereby invest this letter of } \\
\text { privilege with the power of our double } \\
\text { royal seal.] }\end{array}$ & \\
\hline \multirow[t]{3}{*}{$\begin{array}{l}\text { Final } \\
\text { protocol }\end{array}$} & valediction & & $\begin{array}{l}\text { Şi cu aceasta sfirssind, mila lui Dumnezeu să } \\
\text { fie cu d-voastră. [And thus I close my letter } \\
\text { and may the grace of God be upon you.] }\end{array}$ \\
\hline & date & $\begin{array}{l}\text { Anno domini MCCCLVII, quarto Nonas } \\
\text { mensis Martis, regni autem nostri anno } \\
\text { sedecimo. [The year of Our Lord 1357, the } \\
\text { fourth day before the Nonæ of March, and } \\
\text { the sixteenth year of our reign.] }\end{array}$ & $\begin{array}{l}\text { Scris în Tîrgovişte, Ghenarie 13, leatul } 7215 \\
\text { [1707] [Written in Tîrgovişte, the } 13^{\text {th }} \text { of } \\
\text { January, } 7215(1707) \text { ] }\end{array}$ \\
\hline & attestation & & $\begin{array}{l}\text { De bine voitor d-voastră Io Constandin } \\
\text { Voevod [Your well-wishing, I, Constantin } \\
\text { Voivode] }\end{array}$ \\
\hline
\end{tabular}

Since the threefold division of style applied to letter-writing in the Renaissance also occurs in the Romanian epistolography, it is worth mentioning that the rhetorical analysis of some of the letters included in DRH and in other sources outlines an inventory of epistolary stylistic features.

As anticipated in Milică \& Morcov (2016, Secțiunea 2), by the end of the $16^{\text {th }}$ century such erudites as the Flemish scholar Justus Lipsius included in their letter-writing manuals and treatises comments on the qualities of the epistolary style (Figure 1): brevity (brevitas), clarity (perspicuitas), simplicity (simplicitas), elegance (venustas), and propriety (decentia), and thus they became part of the noble rhetorical tradition on the virtues and vices of style (cf. Milică, 2014, p. 41-48).

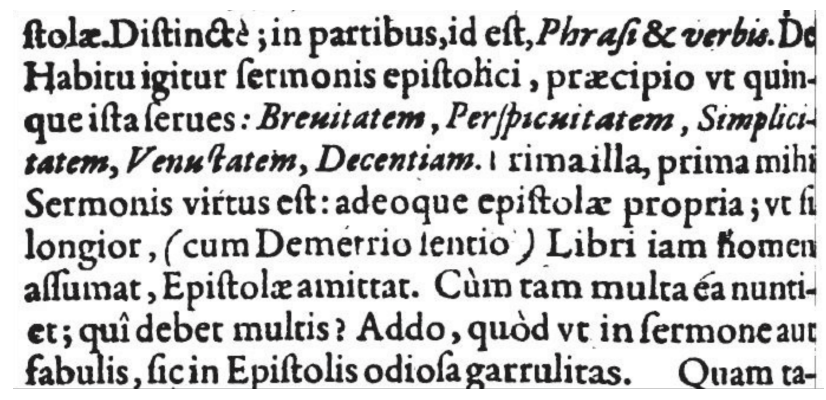

Figure 1: Excerpt from Epistolica Institutio (1591) by Justus Lipsius.

In letter-writing, the virtue of brevity lies in the balance between the relevance of the subject matter and the length of the text. A common subject should be conveyed simply and briefly whereas the complex topic of scholarly and highly formal letters requires a considerable length.

Clarity refers to the precision of language in expressing well defined ideas. This means that letters should be written correctly and rationally.

Simplicity involves straightforwardness and honesty, not ostentation and grandiloquence.

Elegance highlights the author's esprit and erudition. This virtue is of crucial importance in the epistolary style as it emphasizes the middle or the grand style through the use of ornaments like sayings, proverbs, maxims, quotes and other words of wisdom.

According to Aristotel (2004, p. 319), appropriateness (Gr. $\tau \dot{0} \pi \rho \varepsilon \dot{\pi} \tau o \nu$ ) reveals the orator's ability to adapt the discourse to to the subject matter, to his disposition and personality and to the expectations of the audience. Therefore, in oratory as well as in letter-writing, appropriateness mirrors the persuasive forces implied by the relation sender-message-receiver.

From the $17^{\text {th }}$ century onwards, this inventory of stylistic virtues was gradually adopted in letterwriting so that by the 19th century many manuals and treatises of epistolary rhetoric would implicitly 
recommend them as prerequisites of the epistolary ethics and ceremonial as it is the case of Urzescu's letter-writing manual (1840).

\subsection{The functional taxonomy of the Romanian letters in the $16^{\text {th }}$ and the $17^{\text {th }}$ centuries}

The rhetorical features of Romanian letter-writing depend on the internal (linguistic) and the external (extra linguistic) freedoms and limitations that define the epistolary practice from one century to another. Consequently, the typology we suggest for the old Romanian letter-writing is neither infallible, nor exhaustive, but aims at pointing out the main compositional and functional traits of the epistolary style during its formation and development. The theoretical foundation of the taxonomy was inspired by the communicative model proposed by Jakobson (1964), under the influence of the groundbreaking works of Karl Bühler (Bühler, 2011) and Nicolai Trubetzkoy (Troubetzkoy, 1949).

Jakobson's communicative model brings forth the two semiotic axes of the speech act, namely the subjective axis: sender - message - receiver, and the objective axis: context - code (the form of the message) - channel, and enables the classification of letters according to the sociocultural profile and the expressive abilities of the sender (the addresser), to the sociocultural background and the stylistic attitude of the receiver (the addressee) and to the content of the message in relation to a certain context, to a certain linguistic code and to the peculiarities of the channel.

According to the sociocultural profile of the addresser, three main types of letters were identified: letters of the rulers, letters of the high clergy and letters of various officials. In relation to the number of persons involved in the process of letter-writing we distinguish between the unique and the collective sender. It is also important to signal the stylistic differences between male and female senders.

Similar to the focus on the addresser's sociocultural profile, the focus on the sociocultural background of the addressee enables the distinction among letters to rulers, letters to the high clergy and letters to the various officials of the time. The initiative of letter-writing is particularly important in separating the initial letters from letters of response or letters of intervention.

The public - private opposition envisaged by the semiotic solidarity between the message and the context led us to identify two classes of letters: a) the official correspondence, dominated by the legal (judicial and administrative), diplomatic and commercial correspondence, and b) the private correspondence, a class of letters with fewer examples and less productive in terms of structural and functional distinctions.

The code and the channel of communication were also considered to make some fruitful remarks on the ceremonial of letter-writing in Old Romanian.

\subsubsection{The sender}

In early Romanian letter-writing, on the sender's side, the epistolary practices are governed by a conservative tendency in the use of formulae and reflect the tensions between the quasi-mechanical imitation of the conventions imposed by the traditional use of foreign templates and by their relatively creative imitation.

\subsubsection{Letters of the rulers}

The history of the Romanian epistolary style begins in the rulers' chanceries. Shaped by the Latin and Slavonic epistolary cultures, letter-writing finds its first rhetoric encoding that guarantees its functionality, and letters sent by the voivodes during the $16^{\text {th }}$ and the $17^{\text {th }}$ centuries most frequently adopt the formulary outlined in Table 1. With few exceptions, letters begin with the symbolical invocation of the divinity, symbolized by the cross, true to the spirit of an age when man believed that all his actions are overseen by God. The first hallmark in the letters of the rulers is the superscription, an essential constituent and a symbol of the addresser's authority. Opening each document, this fixed formula shows the high level of standardization of the epistolary formulary of the time. The conventional formulae follow the model: "Noi, Vasilie v(oie)vod, cu mila lui Dumnezău, domnu Țărăi Moldovii" [We, Voivode Vasilie, ruler of Moldavia by the grace of God] (DRH A, XXIV/122), and sometimes they may include the filiation: " $\mathrm{Cu}$ mila lui Dumnezeu, Io Alexandru Voevod și domn, feciorul răposatului Io Radu voevod" [By the grace of 
God, Io Alexander, Voivode and Lord, Son of the Late Io Radu Voivode] (DRH B, XXI/224), an element that will also be used by senders of a lesser sociocultural standing. The situations in which the addresser's identity is framed by patterns composed in the Slavonic language, although the document is written in

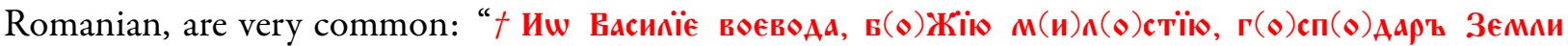
Мшлдавскөи / + Io Vasilie voevoda, bojiiu milostiiu, gospodar Zemli Moldavscoi” [Io Voivode Vasilie, by the grace of God ruler of the Moldavian Land] (DRH A, XXIII/194).

The address or the inscription is a vital part of the letter, also present in the letters of rulers where it is generally introduced by the conventional structure "scrie $(m)$ domnia mea" [My Lordship writes]. When a certain protocol of address is imposed by the sociocultural status of the addressee, this formula is reverentially written in Slavonic, according to the conventional pattern: "Пишем господствө ми честнеишом8 и Бөгъиzврамом8 штъц8 машим8, кир Gирафим, архиепискөп Б8 зовски.” [My Lordship writes the honourable and by God chosen our priest, chir Serafim, archbishop of Buzău] (DRH B, XXXVII/309). Even if it is a compositional element that differentiates letters from other types of documents, the salutation scarcely occurs in the letters of the ruling voivodes in the $16^{\text {th }}$ and $17^{\text {th }}$ centuries, and when it does appear, in a letters exchange with a church official (DRH B, XXXVII/309), with a boyar (DRH B, XXXVII/306) or with a boyar's wife (DRH B, XXXIV/247), it is restricted to the simple formula "sănătate" or its Slavonic equivalent "заравне" [Good health to you!].

Contextwise, these letters display a series of elements that do not characterize letter-writing, but rather other types of documents. For instance, most of the letters written by the rulers include a disposition, especially when addressing the boyars, the monastic communities, the high officials or other recipients in charge of administrative issues. The disposition is introduced by structures such as "Pentr-acea, dacă vei vedea cartea domniei méle" [Therefore, if you see my Lordship's letter] (DRH A, XXVIII/162), "Deci, de vreme ce veți vedea această carte a domnii mele" [Hence, as you see my Lordship's letter] (DRH B, $\mathrm{XXI} / 224)$, and closes with imperative clauses, the so-called proviso, or prohibitive clauses: "Aceasta- $t$ grăiescu domnia mea și într-alt chip să nu faci." [This is my Lordship's command to you, and you shall not act any differently!] (DRH B, XXXIV/247).

In a small number of letters the prohibitive clause is, interestingly, accompanied by the sanction, whose content varies from simple admonition: "bini să știi că mari certare ver avea di cătră domnia mea" [you should definitely know that my Lordship will reprimand you] (DRH B, XXXV/131) to highly persuasive threats: "bine să știți că voiu să tremiț domnia mea om domnescu să vă spargă casele fără de voia voastră. Să nu vă pae într-altu chip!" [you should definitely know that my Lordship will send one of my servants to break into your houses without your permission. Make no mistake about it!] (DRH B, XXXVI/25).

The final protocol of these letters is also distinctive through the absence of the valediction, the exceptions being prompted by the epistolary exchange with the addressees of the same social rank or with the high clergy. Most of the times, the final protocol is written in Slavonic, its content adjusted to the following pattern: "La Iași, in anul $7142<1633>$ sept<embrie > 16. I + Domnul a spus. $1+$ Ghianghea mare $\log <$ ofăt > a invățat. I T Tănasie a scris" [Written in Iasi, in the year $7142<1633>$, September, the $16^{\text {th }} / \dagger$ dictated by His Lordship / † learnt by Ghianghea, the great chancellor / † written by Tănasie] (DRH A, $\mathrm{XXI} / 399)$.

\subsubsection{Letters of the high clergy}

The high clergy includes patriarchs, metropolitans and bishops whose epistolary activity is materialized in letters of damnation, of confirmation, of empowerment or with other functions. These letters are also defined by the utmost uniformity of the formulas which highlights a communicative proficiency governed by the sociocultural status of the addressee.

Crafted around a nucleus that indicates the name, the rank and the region under control, the superscription is different for the patriarch: "† Chiril cu mila lui Domnezeu arbiepiscop cetăție lui Constantin, Rimului Nou și a toată lumea patriiarb" [Chiril, by the Grace of God archbishop of Constantinople, of New Rome, and Patriarch of the entire world] (DRH B, XXII/377), for the metropolitan: "† Милостіï 


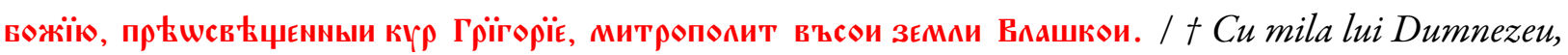
Preasfințitul chir Grigorie mitropolit a toată Țara Ungrovlahiei." [By the Grace of God, his Holy Lordship Grigorie, metropolitan of the Hungaro-Wallachian Land] (DRH B, XXIII/53), and for the bishop: " $f$ Smeritul episcop Serafim al Buzăului" [The humble bishop Serafim of Buzău] ${ }^{4}$. Another fundamental element of structure is the salutation that becomes the communicative sequence in which the addresser assumes the role of a messenger of God's Word: “dar voo s și pace și milă de la Domnezeu a tuturor țiitori și de la domnu nostru Iisus Hristos" [Grace to you, peace and mercy from the All-embracing God and from our Lord Jesus Christ] (DRH B, XXII/377).

Generally prompted by either a person or a group who want to manage their conflicts or to secure their properties by appealing to the authority of the high clergy, most letters are shaped as "letters of anathema" and the focus on the addressee is amplified towards the end of the message, as the proviso and the divine sanction (rarely doubled by the material sanction) build up the framework of a highly intense discourse. Therefore, the letters of the high clergy are structured on the formulae of the Slavonic template, and also bear the stylistic markers of the Biblical epistles, a feature illustrating that they are part of a long-standing tradition which provides this class of letters with the utmost rhetorical stability.

\subsubsection{Letters of various officials}

The members of the chanceries or of other administrative offices, from high-ranking boyars to the village chiefs, were frequently involved in the practices of letter-writing and, as intermediaries between the ruler and the people, enhanced the familiarity of the commoners with the epistolary formulary of the time. These official messages do not deviate from the well-known letter-writing standards and distinguish themselves mainly through the initial and final formulae by which the addresser establishes his relation with the addressee and the degree of formality or, where necessary, the degree of reverence. Both in the correspondence with the voivodes and in the letters to recipients of inferior ranks, the epistolary ceremonial preserves its formality, with inherent differences deriving from the recipient's status or the sender's power and authority. The letters to rulers had to include the address/inscription: "Prea milostive doamne" [Most gracious Lord], the salutation: "Să fii măria ta/dumitale sănătos" [May Your Lordship be in good health], and the valediction. In letters to officials of inferior rank, the importance of the superscription is revealed by the use of Slavonic structures: "Gто аз" [Namely me...], complemented by the filiation: " $f$ Eu Chisar păharnicul, feciorul Chircăi comisul de in Ruda (scris-am la voi satul Groșani)” [I, Chisar, the cup-bearer, son of Chirca, the equerry of Ruda (I am writing to you, the people of Grosani village)] (DRH $\mathrm{B}, \mathrm{XXV} / 347)$, and stresses the social distance between the sender and the receiver.

The letters exchange between interlocutors sharing the same sociocultural status is particularly interesting, because, although they belong to the official correspondence, the letters display strategies of closeness, which are typical of positive politeness. For example, in administrative documents such as letters of request or of intervention, it is possible to notice that the address acts as an intensifier of the persuasive effect: "la ai miei cinstiți și preaiubiți și dulci și dragi părinți mai mari jupînul Lucaci marele bulgăr și la județul cel mare" [to my honourable, well-beloved, sweet and dear elders, master Lucaci the illustrious mayor and the great council of the city of Sibiu] (DRH B, XI/355). The tendency to diminish the formality of the communicative ceremonial and the rhetorical distance between the parties is carried out through such elements as the salutation and the valediction. We can therefore take note that, beside their dominant conative function, such letters also reveal an expressive function.

\subsubsection{The collective sender}

A typical contemporary letter acts as a bridge between one addresser and one addressee. This type of letter is also an instrument of the official correspondence, but it essentially belongs to the sphere of private correspondence, since it is the ideal vehicle for the spontaneous and genuine exchange of thoughts and feel-

\footnotetext{
${ }^{4}$ In this letter, the superscription is superseded by the subscription which indicates the name, the rank, and the region under control: " + The humble bishop Serafim of Buzău". In time, this transposition correlated with an address in the vocative will become more typical for the structure of letters.
} 
ings, having a highly intimate nature. In the $17^{\text {th }}$ century Romanian official correspondence, the instances in which letters are signed by a collective sender are very common, especially if the social relationship between the parties is marked by inferiority - superiority: " $+C i<n>$ stit și de Dumnedzău dăruit părintele nostru, Pătrașco logofätul cel mare, multă viiață și sănătate ca să aibi dumneata de la domnul Dumnedzău, ce-au fácut ceriul și pămîntul și de la preacurata maică și ca să primești dumneata multă închinăciune de la mai mici feciorii dumitale, de la popa Ion den Read și de la Cămîrzan de acolea" [Dear honourable and God favoured father, Pătraşco, high chancellor, we wish you long life and good health from God the creator of heaven and earth and from the Holy Virgin, and we ask you to receive the humble respect of your sons, priest Ion of Read and Cămîrzan] (DRH A, XXII/176).

Due to the low level of education, the lower nobility, the common clergy, and the peasants would address the high officials, the boyars and even the ruler through the intermediary of a professional letterwriter, either to send back word about the fulfilment of some requests, or to make various administrative and legal demands. In their turn, the members of the ruling class conformed to the same epistolary practice if they were ignorant about the rules of letter-writing. This shows that in the old Romanian epistolary style the role distinction (Chițimia \& Toma, 1984, p. 31; Murphy, 2001, p. 204) between dictatores (the message conveyers) and scriptores (the message writers) was active and relevant.

\subsubsection{Letters from men, letters from women}

It is worth mentioning the differences between the male letter writer and the female letter writer. In the epistolary culture of the old times, letter-writing was predominantly a male activity fulfilled by excellence by the clergy or by some members of the legislative authorities. Though considerably less numerous, letters were written by women since the dawn of the Romanian epistolary style. In the light of the collection Scrisori defemei [Letters from women] by Nicolae Iorga, one can notice that women's letters obey the same rhetorical requirements of the official standard of the time. In terms of content, however, these letters stand out as original with regard to the topic, to their style and to their emotional intensity. Women's letters follow the conventions of the typical sequences out of which the superscription highlights the sender's need to legitimize her identity by referring to the male figures of the family when mentioning the filiation or the alliance by marriage: "Ileana Vorniceasa a răposatului Toader Cantacuzino biv Vel Vornic" [Ileana Vorniceasa, wife of the late Toader Cantacuzino, former high steward of the court] (Iorga, 2011, p. 57).

\subsubsection{The receiver}

In line with the stylistic typology of the letters classified according to the sender's sociocultural rank, the old Romanian epistolary style is structured around the receiver's identity as well.

\subsubsection{Letters to rulers}

The correspondence with the political rulers followed a discursive protocol defined by utmost reverence and dignity. The conventional formulae generally used in these letters belong to the structural sequences (the address, the salutation, the valedictions) dominated by the phatic and/or the conative function of the speech act. For example, the address consists of formulae such as "Preamilostive doamne" [Most graceful Sire] or "Milostive și luminate doamne" [Graceful and enlightened Sire], the salutation remains unchanged regardless of the sender's rank: "Să fii măriia ta/dumitale sănătos" [May your Lordship be in good health], and the valediction accomplishes the reverential intensity of the letter: "Dumnezeu să te veselească și să te zilească în ai mulțişi buni, amin”" [May God bless you with happiness and many good years, amen!] (DRH B, XXIV/269).

\subsubsection{Letters to the high clergy}

Aware of the spiritual and legal authority of the receiver, the sender appeals to strategies of address that are essential to the compositional accomplishment of the letters to the high clergy. Depending on the receiver's social rank, on the sender's standing, and on the type of letter, the address, the salutation and 
the valediction are differently crafted, because these sequences always delineate the addresser's attention equally oriented towards the addressee and the context. Even when the emitter is the ruler of the country himself, the initial protocol adapted to the context is minutely polished: "† Мильстієє Божїєю, їш Матєи

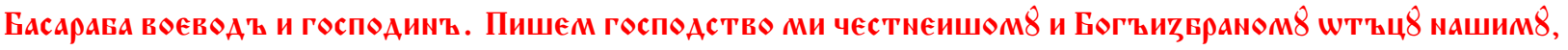
кир Gирафим, архиепископ Б8zовски, заравме.” [By the grace of God, Io Matei Basarab, voivode and lord. My lordship writes to our honourable and God chosen priest, chir Serafim, archbishop of Buzau, good health], as the writer uses a solemn formula of address, "sfinția ta" [your holiness] throughout the letter (DRH B, XXXVII/ 309).

\subsubsection{Letters to various officials}

When the ruler addresses his officials, the salutation and the valediction are omitted, whereas the address is kept as the element that provides the identity and functionality of the letter. Whenever the senders are yeomen, villagers, members of the lower nobility or members of the monastic orders, their letters bear the markers of assumed inferiority and/or humility. In such cases, the salutation and the address are very reverential and may overemphasize the receiver's superiority: " + Cinstite al nostru părinte, dumneata giupine Toderaşco, logofăt mare, să fii dumneata sănătos" [Our honourable father, you, boyar Toderasco, high chancellor, may you be in good health!] (DRH A, XXVIII/70), whereas the subscription brings out the topos of modesty which underlines the rhetorical and social distance between the parties involved in the epistolary exchange: "† Mai mic fecior și sluga dumitale" [Your humble son and servant] (DRH A, XXVIII/70).

\subsubsection{The collective receiver}

Both letters to individuals and letters to collective recipients are of common use in the old Romanian epistolary style. Letters of the second type are particularly interesting as they clearly display the uneven social relationships based on the opposition superiority - inferiority. Most of the times, the letters with collective receiver have a simple address, without insistence on the recipient's individuality, and this marker is present in letters of direct request or intervention: "Scris-am la voi satul Groșani" [I have written to you, the village of Groşani] (DRH B, XXV/347).

\subsubsection{The initiative of writing}

Letters can be classified according to the initiative of writing ${ }^{5}$, irrespective of their public or private nature:

a) initial letters are the most common in public and private epistolary practice, as the addresser is the agent who initiates the letter exchange;

b) letters of reply reflect the recipient's attitude towards the sender's message. If we direct our attention on some of the old Romanian letters, we notice the use of specific phrases, generally introduced after the address, before the exposition, and of other elements that provide contextual continuity. A revealing example is the letter dating from 1635 sent by the voivode Vasile Lupu to the boyar Racovita, in which these typical structures occur immediately after the address: "Scriem Domniia Mea (...) de carte ce ai trimis la Domniia Mea. Ințeles-am scrisorei dumitale...” [My Lordship writes to you (...) about the letter you sent to my Lordship. I understand from your letter that...]. Subsequently, the letter refers to the message already received and it is composed as an elaborated reply whose coherence is emphasized by connectors: "Scrii dumneata cum (...)" [You write that (...)], "Alta, te pobtești dumneata să fii (...)" [Moreover, you want to be (...)] (DRH A, XXIII/194).

c) letters of intervention are sometimes considered variants of initial letters, but their structural and functional identity is given by the fact that the sender assumes the role of intermediary between a third party, not directly involved in the epistolary exchange, and the recipient. Letters of intervention were very common in the old chanceries, since various administrative officials intermediated between the ruler and his subjects, on the one hand, and between two conflicting parties, on the other. Here is a

\footnotetext{
${ }^{5}$ According to this parameter, Vârgolici (2009, p. 67-69) divides the contemporary correspondence in initial letters, letters of reply, and follow-up letters.
} 
relevant excerpt from a typical letter of intervention: "Scriem la priiatinul nostru, la Furtuna ce au fost comis. Dămu-ți știre pentru rândul cestui fecior al nostru, anume Nașcul de Moșetești, cum au $\langle v\rangle$ init de s-au jeluit pre dumneata, cu mare jalobă (...) Pentr-acela lucru, dăm știre, deacă vei vedea cartea noastră, iar dumneata să-l lași foarte in pace" [We write to our friend, Furtuna, the former equerry. We let you know about this young man, Naşcu from Moşeteşti, who came and complained about you (...). It is for this reason that we let you know that, when you see this letter, you must let him be] (DRH A, $\mathrm{XXV} / 413)$.

\subsubsection{The message and the context}

The letter typology is also organized according to the functional opposition public-private. Since the letter is a text that expresses the sender's view on various facts and events, the conveyed message may be interpreted as a semiotic link between its author, the reality and the recipient. Consequently, the differences in form and content between the public (official) and the private (familiar) correspondence illustrate the rhetoric identity of letters as well as the enactment of the referential function.

The drafting rules of the chancery documents favoured a standardization of the old Romanian epistolary formulary, after the Slavonic template (Chițimia \& Toma, 1984, p. 30), In the early stages of letterwriting, the structural similarities between the initial and the final protocols and between the constituent elements of different contexts did not allow an accurate distinction between letters and other types of documents. At the time, the most common classification included three main types of documents (Chițimia \& Toma, 1984, p. 30): acts (royal privileges, commitments between two parties or legal royal letters), letters (any type of correspondence, often independent of any legal foundation), and scripture (short written messages or documents including notes or drafts which often acted as starting points in the elaboration of specific acts, petitions, reports and the like).

The volumes of the Documenta Romanic Historica (DRH) reveal that for such notions as 'act' or 'letter' the scribes used various overlapping terms. This comes as no surprise since, in the Byzantine age, the compositional patterns of the letters did not completely differ from those of other writings often put in epistolary form: homilies, theological, historical or literary writings (Jeffreys \& Kazhdan, 2000, p. 719), probably composed under the influence of the Pauline epistles. In the Romanian formularies, insufficiently explored to ascertain the validity of the medieval thin line between ars dictaminis (epistolary writing) and ars notaria (legal writing), the letter was named carte [written document], and this generic word was used in the titles of some legal documents as well: carte domnească [royal letter], carte de judecată [letter of legal proceeding], carte de mărturie [letter of testimony], carte de proprietate [deed], carte de schimb [letter of exchange], carte de afurisenie [anathema], carte de iertare [letter of indulgence], etc.

In the official correspondence, letters fall under the following categories:

a) The legal and the administrative correspondence, which dominates the old epistolary style. During the $16^{\text {th }}$ and the $17^{\text {th }}$ century, most legal and administrative letters are sent by the voivode, by the high officials, by the village chief, by the regional judge or by the high clergy. One can mention here the numerous letters of disposition from the ruler, such as Vasile Lupu's: "Scriem domnia mea la slugile domniei mele, la aprodzi și la slugi hătmănești (...), Deaca veți vedea cartea domnii mele, iar voi să aveț a lă<sa> in pace țîgani svetii Ipiscopii de Roman (...). Aceasta vă scriem, mai multu val să nu le faceț." [My Lordship writes to my servants, bailiffs and ataman forces (...). When you read my Lordship's letter, do not trouble the gispsies of the holy bishop of Roman (...) This is my will and you must not harm them any further] (DRH A, XXII/152).

b) The diplomatic correspondence; diplomacy is generally defined as the activity, the science or the art of managing the interaction between states. The diplomatic letter, deprived of the advantages of nonverbal communication, becomes efficient through its persuasive content, its rhetorical values, and its compositional protocols which outline the sender's ability to adjust the discourse to the historical and political issues to be negotiated. The principles of diplomatic communication are present in the old Romanian letter-writing especially in the correspondence of the rulers. In a letter from 1599, 
sent by Mihai Viteazul to Ieremia Movilă (DRH B, XI/353), the address preserves its diplomatic solemnity, in spite of the impression of affection: "Scriem fratelui nostru din inimă celui mai iubit, Ioan Ieremia Moghilă voievod, din mila lui Dumnezeu, domn al țării Moldovei" [We write from our heart to our most beloved brother, Ioan Ieremia Moghilă, lord of Moldavia by the grace of God]. Following the etiquette, the salutation reflects the elegant tone that defines the entire letter "Uram domniei sale lungă domnie și sănătate și fericire întru toate” [We wish His Highness long reign, good health and happiness]. The valediction amplifies the solemnity of the message and conforms to the style of the letters to rulers: "Cu aceasta dorim domniei tale de la domnul Dumnezeu sănătate și domnie fericită intru mulți ani” [By this, we wish Your Highness good health and may God bless you with a long and happy reign].

c) The commercial correspondence, which also reflects the stereotypical nature of letters, allows us to understand the manner in which the text can emerge from a communicative ritual performed long enough to first give rise to cognitive schemata and, afterwards, to textual patterns. Thus, the mental schemes associated with any action of exchange generated specific formalized texts (cf. Metzeltin \& Thir, 2013). Many of the old documents are deeds associated to selling, buying or donating, and letters, less numerous, that depict the relationship between two parties involved in a commercial transaction nowadays seen in terms of supply and demand. In such a letter, Ivaşco, a former great 'vornic' is writing to Muşat: "pentru cea delniță ce-ai cumpărat de la Stănești (...), să o lași dumneata săfiepre séama noastră și ți-o voiu prinde in séama celor 18 galbeni" [about that piece of land that you bought from Stănești (...), let it on our account and we shall cover it from your debt of 18 gold coins] (DRH B, XXIII/360).

In contrast with the official correspondence, divided in well-defined categories, a taxonomy of private letters proves difficult to build in the early stages of Romanian letter-writing. Emerging from the communicative rituals stimulated by the impulse towards confession, the private letter, with its intimate and emotional nature, mirrors the writer's unique world-view, being generally accepted as an example of unaffectedness and spontaneity. Private letters are mainly defined by their disregard of epistolary conventions, as they display forms, structures and choices specific to the spoken language. The conventions are only kept with regard to the initial and final sequences and the epistler's creativity is revealed by deviations, omissions and other stylistic innovations. One of the most famous letters, dated around 1600, is the letter of Cocrișel (DRH B, XI/419), who, after being taken prisoner of war, wrote to his parents to inform them about his situation and his attempts to regain freedom. The content is defined by the writer's expressiveness and by the familiar tone that governs the discourse. The form reflects the writing norms of the time. The initial protocol is reduced to a single sentence which concentrates the typical constituents, the symbolical invocation, the salutation and the address: "† Scriu închinăciune și moltă sănătate părinteloi meu Spiridon și maiciei mele Costandeei" [I am devotedly yours and I wish you good health, my father Spiridon and my mother Costandeea]. The content information included in the letter's context is adjusted to the epistolary conventions, and the final part consists of the valediction: "Şi să afle aiasta scrisoare a mea sănătoş pre dumeavoastră, o Gospodi, amin" [May this letter find you both in good health, o Gospodi, amen] and of the subscription: "Feciorul vostru Cocrişel" [Your son, Cocrișel].

In spite of the highly phatic nature of the letter-writing conventions, Cocrișel's letter displays an obvious emotive function. It flows as a confession which, by its dramatic tone, aims at moving the addressee, and the unaffectedness and sincerity shine through the expressive choices that bring it closer to the spoken language: "mămănîncă lutul șipăduchie" [my body itches with lice and dirt]; "mor de dorol vostru" [I miss you dearly]; "barbă pînă-n brîu” [waist-long beard]. This is the period when the private letter blends the familiar forms of address suited to specific contexts with the official templates which are typical for the medieval letter.

The private communication in which the letter asserts its intimate nature, its relative freedom from conventions and its role of intermediary between two people faced with the impossibility of direct interaction highlights different facets of the addresser such as the soldier gone to war, the man deprived of freedom, the person involved in correspondence with family and friends, the lover and so on. 


\subsubsection{The channel and the code}

The communicative channel typical for the letter is writing. Most of the letters preserved from the Romanian Middle Ages are not autograph writings and, although the epistle's vocabulary frequently record the forms of the verb in the $1^{\text {st }}$ person scriu/scriem [I write / we write], the final arrangement and the observance of the writing standard are not usually carried out by the addresser, but by the scribe who thus becomes an intermediary between the parties. His identity is announced inside the letter's body by structures such as " + Tănasie <a scris $>$ " [ $<$ Written by > Tanasie] (DRH A, XXI/399), inserted in the final protocol. Letters were commonly written on paper, the parchment being used only for solemn documents written in Slavonic. It is worth mentioning that in the early stages of Romanian letter-writing the use of the two channels, the written and the oral, was very common in official communication. The preference for the oral transmission of the important messages was a political strategy adopted by the medieval rulers and, implicitly, a particularity of the time's diplomatic correspondence. Such sequences as " + Rogu-mă măriei tale să crezi pre omul nostru, pre Gligorie postealnicul, de ce va grăi." [I ask your Lordship to trust the words of our man, Gligorie] (Chivu et al., 1979, p. 110) become rare as time goes by.

In the first part of Section 3 (Milică \& Morcov, 2016), we noticed that the cultural evolution of the Romanian letter-writing developed under the influence of some foreign models, the most important being the Slavonic template. During the $16^{\text {th }}$ century, the tendency to compose letters by means of foreign patterns gradually gave way to the initiative of writing the official and private letters in Romanian. In the following century, Romanian became the standard language of letter-writing, though the letter was still affected by the long use of the Slavonic model, a defining trait which can be seen in the intertwining of the two linguistic codes. The phatic ceremonial of the epistolary exchange is revealed by the introduction of Slavonic elements in the initial and the final protocols even if the rest of the letter is written in Romanian. The fact that the superscription (especially in the ruler's letters), the place and the time of writing, and, at times, the valediction and the scribe's identity, that is all the elements with a fixed structure, mirror the Slavonic template suggests the existence of a simplified formulary used in letter-writing.

Gradually, the use of the old language of culture is limited to some royal documents which indicate the habit of appealing to a familiar template, on the one hand, and the strategy to amplify the persuasive potential of the ruler's letters, on the other. In the $17^{\text {th }}$ century the Slavonic code is preserved by virtue of tradition as well as to provide solemnity to the chancery documents, especially while drawing up the letters of donation, protection of rights etc. Furthermore, arenga, a rhetorical ornament otherwise rarely used in the diplomatic documents of the time, is introduced only in the letters entirely drafted in Slavonic and written on parchment, an elegant and precious material. Thus, in a period of time when the writings in Romanian stress their functionality in various fields of activity, public or private, the Slavonic language often becomes the symbol of religious solemnity.

\section{Bibliography}

*** (1964) Rhetorica ad Herennium [Ad C. Herennium de ratione dicendi], with an English translation by Harry Caplan, William Heinemann Ltd., London, Harvard University Press, Cambridge, Massachusetts.

Aristotel (2004). Retorica, bilingual edition, translation, introduction and index by Maria-Cristina Andrieș, notes and comments by Ștefan-Sebastian Matei, Editura Iri, București.

Bly, R. W. (2004). Webster's New World Letter Writing Handbook, Wiley Publishing Inc., Indianapolis, IN.

Bühler, K. (2011). Theory of Language. The Representational Function of Language, translated by Donald Fraser Goodwin in collaboration with Achim Eschbach, John Benjamins Publishing Company, Amsterdam - Philadelphia, Crossref.

Chițimia, I. C. \& Toma, S. (coord.) (1984). Crestomație de literatură română veche, vol. I, Editura Dacia, Cluj-Napoca.

Chivu, Gh. (2000). Limba română de la primele texte până la sfârșitul secolului al XVIII-lea. Variantele stilistice, Editura Univers Enciclopedic, București.

Chivu, Gh., Georgescu, M., Ioniță, M., Mareș, Al. \& Roman Moraru, A. (eds) (1979). Documente și însemnări românești din secolul al XVI-lea, Editura Academiei R.S.R., București.

Cicero (1939). Brutus. Orator, translated by G.L. Hendrickson, H.M. Hubbell, Loeb Classical Library, Harvard University Press, Cambridge, MA. 
Donescu, C. (1840). Epistolariu culesu shi întocmitu asfelu, Tipografia lui Eliad, București.

Dumistrăcel, S. (2007). Limbajul publicistic din perspectiva stilurilor funcționale, Editura Institutul European, Iași.

DRH A = Documenta Romanie Historica. A. Moldova, Editura Academiei Române, Bucureşti, 1969-2006.

DRH B = Documenta Romaniæ Historica. B. Țara Românească, Editura Academiei Române, Bucureşti, 1965-2006.

DRH C = Documenta Romanie Historica. C. Transilvania, Editura Academiei Române, București, 1981.

Iorga, N. (1925). Scrisori de boieri. Scrisori de Domni, Aşezămîntul tipografic “Datina Românească”, Vălenii de Munte.

Iorga, N. (2011). Scrisori de femei, Editura Vremea, Bucureşti.

Irimia, D. (1999). Introducere în stilistică, Editura Polirom, Iași.

Jakobson, R. (1964). Lingvistică și poetică. Aprecieri retrospective și considerații de perspectivă, in Probleme de stilistică, translated by Mihail Nasta in collaboration with Matei Călinescu, Editura Științifică, București, p. 83-125.

Jeffreys, E. M. \& Kazhdan, A.P. (1991). Epistolography, in Kazhdan, A.P. (ed.), The Oxford Dictionary of Byzantium, vol. I, Oxford University Press, Oxford - New York, p. 718-720, Crossref.

Mack, P. (2011). Letter-Writing Manuals, in A History of Renaissance Rhetoric 1380-1620, Oxford University Press.

Metzeltin, M. \& Thir, M. (2013). Antropologia textului, translated by Octavian Nicolae, Editura Universității „Alexandru Ioan Cuza”, Iași.

Milică, I. (2014). Noțiuni de stilistică, Editura Vasiliana '98, Iași.

Milică, I. (2015). Funcțiile stilului în retorica creștină a Sf. Augustin, in “Diacronia”, 1, Jan. 13, art. A7, Crossref.

Milică, I. \& Morcov, I. (2016). Scrisul epistolar românesc: o perspectivă cultural-retorică (I), in “Diacronia”, 3, Feb. 12, art. A39, Crossref.

Murphy, J.J. (2001). Rhetoric in the Middle Ages. A History of the Rhetorical Theory from Saint Augustine to the Renaissance, Arizona Center for Medieval and Renaissance Studies, Tempe, AZ.

Troubetzkoy, N.S. (1949). Principes de phonologie, traduits par J. Cantineau, Librairie C. Klincksieck, Paris.

Urzescu, V. (1840). Epistolar sau modele de scrisori pentru tot felul de trebuințe, cules din cei mai vestiți autori noi și vechi, franțezi și alți cu formulele politeții moderne..., Tipografia Pitarului Constandin Pencovici, București.

Vârgolici, N. (2009). Redactare și corespondență, Editura Universității din București, București. 